\title{
Diverging or converging dynamics? EU and US policies in North Africa - An \\ Introduction
}

\author{
By \\ Dr. Francesco Cavatorta \\ School of Law and Government \\ Dublin City University \\ Glasnevin, Dublin 9 \\ Ireland \\ E-mail: Francesco.cavatorta@dcu.ie
}

and

Dr. Vincent Durac

School of Politics and International Relations

University College Dublin

Belfield, Dublin 4

Ireland

E-mail: vincent.durac@ucd.ie 
According to a number of scholars of international relations, the transatlantic relationship is going through a very significant and possibly irreversible crisis. It is claimed that the different reactions of the United States and the European Union to both September $11^{\text {th }}$ and the war in Iraq were the catalyst for a rift that had been deepening for some time, leading to competition between the two actors. The literature on the foreign policy of the US and the EU in the Middle East and North Africa also points to this rift in order to explain the seemingly contradictory policies that the two actors implement in the region, with the US being more forceful in its attempts to export democracy and in supporting Israel while the EU adopts a less confrontational attitude and is perceived to be more friendly to the Palestinians. This article, which introduces a special issue on the nature of US and EU foreign policies in North Africa, argues on the contrary that the transatlantic rift does not really exist. While there are certainly differences in discourse and policies, both the EU and the US share the same concerns and have similar strategic objectives in the region, leading to the two actors towards cooperation and division of labour rather than confrontation.

Key words: transatlantic relationship - realism - normative Europe - political Islam

In a recent article on the state of the transatlantic relationship, Asmus (2003) forcefully argued that the EU-US alliance had finally collapsed and that the two now former partners were headed for confrontation on a number of international issues. While other scholars do not share this extreme view, they agree with Asmus that the rift between the two is indeed very significant (Neuhold, 2003) and the current literature on transatlantic studies gives increasing prominence to this issue (Forsberg and Herde, 2006). The preoccupation with the state of the Atlantic Alliance has always been a constant feature in the literature on transatlantic studies, but recent policy differences and misunderstandings ranging from environmental politics (the Kyoto protocol and subsequent negotiations) to hard security matters (Iraq and Iran) to the substance of liberal values (the death penalty) have been interpreted as being qualitatively different from past ones and indicative of a serious and possibly irreparable split. In the past, rifts were short-lived and quickly mended for a number of reasons. First of all, the US was perceived to be a more accommodating actor, ready to listen to its partners and willing to pursue multilateral strategies, while the European Union was internally divided, unable to sustain common positions and therefore more readily influenced by the United States positions. In addition, the common threat of communism and the existence of shared liberal democratic values made the alliance both inevitable and strong. Today, it is argued that the situation is very different. The European Union has acquired much stronger internal coherence in 
a wide range fields, but in particular it has strengthened the one policy area where it used to be at its weakest and it now has a Common and Foreign Security Policy (CFSP), which, despite contradictions and problems, is much more effective than in the past. This has been translated in a more assertive international role, which reflects the constitutive values and beliefs of the Union leading to significant differences with some of the positions and interests of the United States. Such differences, realists would argue, are determined by the different positions that the two countries occupy in the international system. At the same time, the United States, particularly with the George W. Bush administration, has become less interested in multilateralism and acts in accordance with its own perceived status as the only remaining superpower. While this trend accelerated after September $11^{\text {th }} 2001$, it was in evidence before then a by-product of the end of the Cold War. In addition to all of this, the ending of the global communist threat has weakened the previous bond and, crucially, made the world multi-polar. Accordingly, this systemic change seemingly placed the United States and the European Union as competitors on the new international scene and undermined further the previous political, economic and strategic proximity. The shift of the international system from bi-polar to multi-polar is however not the only explanation for the parting of ways of the United States and Europe. Another powerful explanation for the existence of such a deep rift is said to stem from profound constitutive differences related to the theoretical understanding that both actors have of themselves and of the surrounding international system. The EU perceives itself to be the ultimate good citizen in international politics because of the very manner and values upon which the Union was first set up. The European project is one based on incessant multilateral bargaining and compromising underpinned by democratic norms of decision-making, which make the Union, when operating as on the international scene, a normative actor. Coercion never entered the picture in the process of building Europe and it is only through time-consuming negotiations that an increasing number of policy areas came under the control of European institutions. This peaceful process of 'unification' through the sharing of democratic values and through economic integration is at the heart of the Union's belief system. When this is translated into foreign policy-making, the Union conflates its own interests with the interests of all the other countries it comes into contact with and attempts to export its values and norms through a process of multilateral constructive engagement based on positive inducements and conditionality. The nature of the EU is to make other 
countries behave accordingly to the norms that are at the heart of the EU because these are universal and 'good' (Manners, 2002). It is a process of osmosis where coercion does not feature. It follows that the EU does not perceive itself as a confrontational actor and aims at expanding the area of democratic peace through peaceful means even if this takes a long time and requires overcoming significant setbacks. The basic idea at the heart of the European Union is that the same process of integration that characterised the birth of the EU itself can be repeated ad infinitum across the world because it is centred on universal norms such as democracy and human rights. In sum, the EU embodies the very concept of 'soft power' (Nye, 2004) that the United States can no longer employ. This self-perception and the projection of this perception in international relations are very different from the one the United States have. While the US also conflates its security with the security of humankind and promotes universal values, it faces the problem of being, contrary to the EU, a national community and therefore subject to accusations of promoting its own narrow national interest in the name of universality. In addition, the United States is a much more forceful actor, ready to wage war when it sees it fit and much more ideological than its European counterpart. The EU obviously shies away from active conflicts due to the inability of its institutions to make a decision over such an important matter because, contrary to the US, it does not have 'national unity', but the role of norms in determining the non-confrontational nature of the EU should not be underestimated. The US process of nation-building and later the role of leading the 'free world' created a different set of norms and values from the ones the EU was built on and where political 'realism' was much more present. For those who believe that the Atlantic Alliance is indeed finished it is therefore not difficult to explain such occurrence by pitting the 'liberal realism' of the United States against the 'liberal normative constructivism' of the European Union.

In this respect the war against Iraq has simply been interpreted as the catalyst of an existing trend, which has led Europe away from the United States in international politics. While it is true that the European Union was unable to reach a common position on Iraq with different countries choosing opposing courses of action undermining the CFSP in the process (Chari and Cavatorta, 2003), it is also worth highlighting that it did not support the United States either. More significantly, for the vast majority of European citizens, the decision to go to war was largely believed to be another demonstration of US imperialism, which would damage international 
peace and stability rather than strengthening them. This is also true in some of the European countries, namely Spain and Italy, whose leaders decided to join the United States and who were later dismissed from office partly because of that decision. Among policy-makers this has not gone unnoticed and the war on Iraq accelerated the European process of solidifying the common foreign policy in order not to arrive at the next international crisis in such a divided manner. Given the profound differences on Iraq between the EU and the US, it is not surprising that those claiming the existence of the rift increasingly point to the Middle East and North Africa as the region where the constitutive differences of the US and the EU lead to clashes of interests and policy divergences. This can be seen 'with the US adopting a very forceful pro-democracy promotion attitude, coupled with a strong support for Israel and for military intervention if necessary, while the European Union, both rhetorically and through some concrete measures, adopts a more pro-Palestinian stance and a softer approach to democracy promotion' (Durac and Cavatorta, forthcoming 2008). Even on democracy assistance in the region, there are significant differences between the EU and the US, as Huber (2008) highlights in her study.

The existence of such a deep rift between the two actors is however not unanimously accepted and there are in fact strong doubts not only about its depth, but about its existence too. The basic claim is that the current rift can be repaired very quickly because there are both strategic coherence and shared values between the US and the EU. While there might be differences on the two sides of the Atlantic on how to tackle a specific problem such as the Iranian nuclear programme, these differences never spill over into open confrontation and competition. In addition, while it is true that the European Union increased its level of internal coherence on foreign policy matters, the Union's institutions remain largely marginal when it comes to deal with significant international crises and member states usually take over. On its part, the United States acts no differently today than in past decades and the extreme unilateralism of the Bush administration has diminished over time and is likely to be severely toned down with a new administration in place in 2009. It should also be recognised that the collapse of communism did not really trigger a significant amount of competition between the EU and the US, as the two actors did not have a falling out on how to best manage the transition from the Cold War to a new world order. If anything their ties have been considerably strengthened because in the face of a range of new threats they have often acted together to counter them, as the war against Iraq 
in 1991 demonstrates. Furthermore, globalisation has solidified the level of economic, cultural and military integration between the US and the EU, which have benefited from operating together to open markets in the developing world and creating new rules for international trade that are beneficial to both actors. The creation and strengthening of multilateral institutions where their shared interests are promoted are testimony to the fact that the two actors have still very much in common and their destiny is tied together. The Middle East and North Africa therefore do not represent an example where the diverging conceptions of international relations the EU and the US have battle it out for supremacy. It follows that Iraq did not represent the point of no return for the US-EU relationship, but simply a temporary tactical divergence. Irrespective of what the US 'surge' might achieve, the Iraq adventure has proven to be a failure for the Bush administration and we are now witnessing a return to multilateralism and consultation with the EU partners on how to best proceed to achieve regional peace and stability. The rift is therefore not serious because both actors largely share the same theoretical assumptions about the nature of international relations and behave therefore accordingly. What both actors want is to remain the dominant forces on the international system and although they might espouse diverging tactics at certain moments in time, their strategic concerns largely coincide and they therefore very often work together to achieve their most preferred outcomes by combining their respective strengths (Musu and Wallace, 2003). Converging dynamics then characterise the relationship because each actor brings a different but complementing set of resources and capacities.

In the case of the European Union, there is for instance an increasing amount of work (Youngs, 2004; Hyde-Price, 2006) highlighting how the perception and selfperception of the EU as a normative actor is misplaced. Far from being a uniquely 'good and moral citizen' selflessly promoting democracy and human rights, the EU is also realist actor, which utilises its best assets, namely reputation and money, to achieve very concrete realpolitik interests such as conquering new markets, strengthening its own internal security, preserving its borders and marginalising in the process issues of democratic governance and respect for civil liberties. This is an accusation often made against the United States, but a more in depth analysis reveals that the EU behaves in a similar manner, although it is better equipped to project a largely positive image of itself. In many respects therefore there is a very significant degree of convergence in the policies and strategies of the EU and the US at the 
global level. Both actors fear the rise of China as a global power, are weary of the rise of India, are not impressed by the South American 'new left' and share similar preoccupations about nuclear proliferation, terrorism, migration and access to energy resources. When it comes to the Middle East and North Africa, there is a shared reluctance and therefore a strategic agreement on the necessity of avoiding radical Islamists getting into power even to the detriment of the democratic process (Cavatorta, 2001; Ghalioun, 2004). There is also the imperative of securing access to energy resources and to expand markets through free trade agreements that only authoritarian rulers can guarantee as the example of Morocco, which signed free trade agreements with both the US and the EU, emphasises. Finally, there is the shared objective of maintaining Israel as the primary regional power. No one denies that there are tactical differences between the EU and the US on how to best promote and defend these strategic goals, but such differences can be hardly seen as the evidence for the existence of a deep rift when in fact strategic concerns are so similar.

Thus, there are two conflicting views on the nature and the current state of the transatlantic relationship leading to important questions about the theories of international relations' abilities to account for the foreign policies of the two most relevant actors on the international scene. Does a rift really exist between the EU and the US? If so, which theory best explains it? If not, how can one account for it when, seemingly, systemic rearrangements in the distribution of power would indicate that a split is inevitable? These questions are even more significant when the impact of these foreign and security policies is examined in the context of the most unstable region in the world: the Middle East and North Africa (Hinnebusch, 2003).

This collection is based on a novel comparison of the foreign and security policies of United States and the EU in North Africa. While there are a number of works outlining how each actor deals with the most pressing regional issues (Gillespie and Youngs, 2002; Junemann, 2004; Cook, 2005; Dalacoura, 2005) and how each partner perceives the other's policies in the region (Perthes, 2004), there is very little work done to compare how the two actors operate. More specifically, this collection aims to clarify two issues related to this topic. First of all, it seeks to highlight whether the foreign policy dynamics of the United States and the European Union in the region are converging or diverging. Building on the theoretical debate summed up above, it is necessary to compare whether the strategies and the policies implemented 
in the MENA confirm or disprove the existence of a fundamental rift between the EU and the US. These broad theoretical analyses need to find substantiation in the empirical analysis and the findings can then be used to answer a number of important theoretical questions. If evidence of divergence does indeed emerge, how is this relevant to our understanding of international relations? Would such evidence confirm the currently held assumption about the liberal and normative traits of the European Union's foreign policy and therefore automatically lead to assume that the rift with the US is irreparable? If, on the contrary, evidence of convergence emerges, how would this affect the theoretical understanding of the European Union in light of the realism that the US displays? Would one then be able to question the very idea of the EU as a good international citizen? Finally, would one have to assume that the United States is the narrow minded ideological actor that many make it out to be, always looking out for its own interests to the detriment of values and norms?

The second issue, which this collection deals with, is the relationship or lack of thereof between the two international actors and Islamists. There is very little doubt that the existence and appeal of radical political Islam has been and continues to be the most serious element of preoccupation for the international community. The success of the Arab-Israeli peace agreement, the different democratization processes, economic development and access to natural resources are all believed to hinge on the absence of Islamists from power. There are two inter-connected reasons for this. First of all, it is widely held that Islamists are inherently undemocratic and therefore any success they might have would result in countries becoming significantly more authoritarian than they are now (Zakaria, 2004). Secondly, Islamists, irrespective of their democratic or un-democratic nature, are believed to be inimical to the West and therefore it is assumed that once in power they would implement policies that would negatively affect western interests in the region. Thus, Islamists are central to the foreign policies of the United States and the European Union. It follows that it is important to examine how these two actors approach the issue of political Islam and how the latter informs the foreign and security policies of the former. Linked to this, we aim at measuring the degree of success that the current foreign and security policies are having on radical Islamist groups. The rift between the United States and the European Union is perceived by some to be profound because the EU appears to be the 'good cop' in the region, while the United States is the 'bad one'. Does this 
truly reflect the reality or it a construct? More importantly, how does the Islamist other view the two actors and their policies?

Following this introduction, the collection opens with a broad review of the economic diplomacy of the United States and the European Union. Both the EU and the US operate under the assumption that democracy would inevitable lead to the end of terrorism and to economic development with its corollary of peaceful state relations. Thus, one of the ways in which this objective of security is through the reform of the economic institutions of target countries despite the fact that there is ample evidence to demonstrate that neo-liberal economic reforms are usually hijacked by the MENA ruling elites (Dillman, 2001). In his contribution, Patrick Holden therefore examines the debate on cooperation and competition between the United States and the EU by looking at economic diplomacy. Holden argues quite convincingly that the preeminence of converging dynamics is quite evident and that neither actor "is likely to have a transformative impact on the institutions of the region.' Rather than focusing on hard security policies or democracy promotion strategies, Holden analyses the economic instruments that both actors use to achieve 'security' in North Africa, following the theory that increased economic ties and development would lead to cohesion and stability. Holden postulates that the EU and the US should compete as economic actors in the region because they have similar needs to expand markets and gain access to increased energy resources. Such competition does indeed exist and takes the form of bilateral aid and bilateral free trade agreements for the US and of multilateral agreements and closer economic integration for the European Union. All this however is not sufficient to demonstrate that the competitive mode is the dominant one because the liberalizing and globalising agenda both actors have is largely the same and leads to the same sets of problems and issues for the target countries, namely a rise in disaffection with the ruling elites, which, in turn, affect the hard security pillar. When it comes to hard security the convergence of two actors is again dominant and Holden concludes that geo-economic competition does not trump the geo-strategic one. This is particularly relevant when one deals with the theoretical implications of such findings, which seem to point to two contradictory points. On the one hand, the 'timeless wisdom of realism' (Buzan, 1996) as an explanatory framework for international relations seems to prevail given that core national interests in the name of security prevail over economic ones. On the other hand 
however, such 'timeless wisdom' has to be questioned given that two of the most powerful actors in the system opt for co-operation rather than competition, as it should be natural in a Waltzian anarchical world.

Broad-ranging comparisons are very useful to highlight trends, but their conclusions might not apply across the board. It becomes then imperative to examine in some detail how the dynamics of convergence and divergence operate with respect to individual countries. Yahia Zoubir and Hakim Darbouche trace and contrast European and US reactions, attitudes, and policies towards the Algerian crisis to determine whether the cooperative or the competitive trend is the dominant one. It thus emerges that when it comes to the complex Algerian case, the United States and the European Union have had significant differences on how to deal with the crisis and that, at different points in time, the two actors were even in opposition to each other on the course of action to be chosen. This does not mean that competition dominates, but it indicates that in the Algerian context EU/US relations can be better defined as a division of labour rather than convergence. As they state, 'the reactions the crisis induced in Europe and the United States were informed by different strategic and normative considerations.' The lessons from the Algerian case the two actors learned have been employed elsewhere and point to similar attitudes, with a toughening stance of the European Union towards Syria and Palestine in line with US attitudes and a softening stance of the US towards dictators like Qhadafi in line with EU behaviour. Brieg Powel, in his study on Tunisia, does not find any indication of significant competition. Tunisia is an often forgotten case study because of its relative small size, marginal geographic position, and political stability, but it represents a very important laboratory to examine authoritarian rule, economic liberalisation and Western patronage. Compared to the other countries in the region, Tunisia has no significant radical Islamist opposition, it enjoys a degree of economic success and has a rather liberal legislation on matters such as women rights. Furthermore, Tunisia is truly integrated in the global economy and has strong trade links with the EU. It would therefore seem the perfect place where to attempt to export democracy. Powel however finds that both the United States and the European Union are satisfied with the way in which Bin Ali governs the country and this despite the widespread evidence of human rights abuses, absence of political freedoms and lack of genuine institutional reforms. Powel concludes that both the US and the EU 'have shifted their 
focus to maintaining stability through the status quo rather than risk unpredictable outcomes.' In many ways Tunisia illustrates the contradictions that are at the heart of the foreign and security policies of both actors in the region. Similar findings emerge from the Egyptian case that Vincent Durac examines. Here again emerges the contradiction between democracy promotion as enhancement of security and the fear of democracy that features prominently in both the discourse and the practice of the EU and the US. Even more strongly than in the Tunisian case, the United States and the European Union, through the provision of material and legitimacy resources, prop up the Mubarak regime due to the pivotal role of Egypt in the region. Durac argues that Western policies support the entrenchment of authoritarianism in Egypt and explains how both the US and the EU undermine their rhetorical pro-democracy stances through the implementation of flawed policies. While the US rhetoric on democratization in the region became much stronger in the aftermath of September $11^{\text {th }}$, very few significant concrete policy initiatives occurred. In a much publicised trip to Egypt in 2005, Secretary of State Rice did indeed criticise the regime and encouraged Mubarak to hold multi-party and multi-candidate elections, but she never met with the most popular opposition (the Muslim Brotherhood) nor did she hold Mubarak accountable for its subsequent clampdown on political opponents. The EU was softer in rhetoric as it prefers to encourage authoritarian regimes through positive inducements and engagements, but the outcome was largely the same when it came to implement concrete policy changes that would upset the Egyptian regime: nothing was done. Zemni and Bogaert in their analysis of Morocco adopt a somewhat different approach to explore how the United States and the European policies influence the region. Rather than comparing and contrasting how the two actors operate with respect to Morocco and then drawing conclusions, the two authors set their investigation within the parameters of the globalisation debate. Zemni and Bogaert assume that the policies of democratization that the US and the EU have in place are similar because they are framed within the logic of neo-liberal globalisation. Their focus is therefore on the economic aspect of the relationship and the authors convincingly argue that 'the central problem of political and economic reform lays in the ways it is conceptualised and implemented through a fee market ideology.' In this context, the free-market ideology is supposed to deliver not only economic development, but also peace and security. What clearly emerges from their analysis is that states and quasi-states entities might not have the degree of control they believe 
over the policies they implement because they are 'delegated' to the free market, which interprets them and modifies them according to its own logic. The outcome is therefore a policy realm where the forces of globalisation take over and where state actors, although not marginalised, have to re-invent a role for themselves at the service of economic market forces. In the end, this attempt to generate security and stability through the free market fails precisely because it creates 'forces' beyond the control of states that undermine the very objectives of the original policies. This occurs because the free market ideology only delivers success for a selected few, while worsening the situation of the vast majority, which is further driven towards radicalism defeating then the security objectives. The last contribution deals precisely with the beneficiaries of the discontent of the majority of citizens in the Middle East, namely Islamist groups. Pellicer-Gallardo and Wegner carry out an empirical analysis of the determinants of Western support for authoritarian regimes in the Middle East and North Africa. This analysis obviously is centred on the role that opposition Islamists play in this 'game' although the statistical analysis they undertake does not deal with the directly but only by proxy.. What emerges from the study is that there is a convergence of reasons for the United States and the EU to support authoritarianism, but, interestingly, there are also differences in motivation. When countries are strategically irrelevant, both the French and the US take into account the degree of political and civil liberties that exist in the country, favouring the more 'liberal ones'. When countries are strategically relevant this normative stance disappears and aid is linked to regime survival. This is linked to the presence of Islamist movements that might promote anti-Western policies once in power. Overall, more aid goes to strategically relevant countries than to non-relevant ones. Again this makes sense if the objective is stability. Thus, despite providing aid to different countries, both the US and the French, utilising at times EU institutions, have very similar motives. This points again to a division of labour rather than open competition between the two actors. It also is worth mentioning that the study finds that 'although French and US foreign aid goes to different countries, the underlying motives are remarkably similar. Finally, to the extent that there is a difference between the two countries, France fairs worse than even US military aid regarding the consideration of civil and political liberties.' This is a very interesting finding in so far as the much vilified United States seems actually more interested in civil and political liberties 
than the key European actor and dominant power in EU policy-making with respect to North Africa.

Taken together, these studies provide a better understanding of the state and nature of the transatlantic relationship in all its facets. What emerges quite clearly is that there is much more convergence than divergence between the EU and the US when it comes to the Middle East and North Africa. Whether we examine democracy promotion or strategies of economic development for the region, we find that the two actors cooperate because they have shared strategic concerns and their policies fall short in similar ways because riddled with similar contradictions. For the moment, it seems that the act of 'good cop (EU)-bad cop (US)' is working in so far as the European Union is not perceived yet as a civilisations enemy by opposition movements throughout the Middle East and North Africa, can the act last for much longer given the EU's continued inability to live up to its reputation of normative international citizen?

\section{REFERENCES}

Asmus, Ronald (2003) 'Rebuilding the Atlantic Alliance', Foreign Affairs, 82(1), pp. 20-31.

Buzan, Barry (1996), 'The Timeless Wisdom of Realism?' in International Theory: Positivism and Beyond in Steve Smith, Ken Booth and Marysia Zalewski (eds.) Cambridge, Cambridge University Press.

Cavatorta, Francesco (2001) 'Geopolitical challenges to the success of democracy in North Africa: Algeria, Tunisia and Morocco', Democratization 8(4), pp. 175-194.

Chari, Raj S. and Francesco Cavatorta (2003) 'The Iraq War: Killing Dreams of a Unified EU?', European Political Science, 3(1), pp. 25-29.

Cook, Steven (2005) 'The Right Way to Promote Arab Reform', Foreign Affairs, 84(1), pp. 91-102.

Dalacoura, Katerina (2005) 'US Democracy Promotion in the Arab World since September 11 2001: a Critique', International Affairs, 81(5), pp. 963-979.

Dillman, Bradford (2001) 'Facing the Market in North Africa', Middle East Journal, 55(2), pp. 198-215.

Durac, Vincent and Francesco Cavatorta (2008) 'Strengthening authoritarian rule through democracy promotion? Examining the paradox of the US and EU security 
strategies. The case of Tunisia', British Journal of Middle Eastern Studies, forthcoming.

Forsberg, Tuomas and Graeme P. Herde (2006) Divided West. European security and the Transatlantic Relationship, London, Blackwell.

Ghalioun, Burhan (2004) 'The Persistence of Arab Authoritarianism', Journal of Democracy, 15(4), pp. 126-132.

Gillespie, Richard and Richard Youngs (eds.) (2002) The European Union and Democracy Promotion: the Case of North Africa, London, Frank Cass.

Hinnebusch, Raymond (2003) The International Politics of the Middle East, Manchester, Manchester University Press.

Huber, Daniela (2008) 'Democracy assistance in the Middle East and North Africa: a comparison of US and EU policies', Mediterranean Politics, 13(1), pp. 43-62.

Hyde-Price, Adrian (2006) 'Normative power Europe: a realist critique', Journal of European Public Policy, 13(2), pp. 217-234.

Junemann, Annette (ed) (2004) Euro-Mediterranean Relations After September 11: International, Regional and Domestic Dimensions, London, Frank Cass.

Manners, Ian (2002) 'Normative Power Europe: A Contradiction in Terms?', Journal of Common Market Studies, 40(2), pp. 235-258.

Musu, Costanza and William Wallace (2003) 'The Middle East: Focus of Discord' in John Peterson and Mark A. Pollack (eds.) Europe, America, Bush: Transatlantic relations in the twenty-first century, London, Routledge.

Neuhold, Hans Peter (2003) 'Transatlantic Turbulences': Rift or Ripples?', European Foreign Affairs Review, 8(4), pp. 458-468.

Nye, Joseph (2004) Soft Power: the Means to Success in World Politics, Public Affairs Publishing.

Perthes, Volker (2004) 'America's "Greater Middle East" and Europe: Key Issues for Dialogue', Middle East Policy, 9, pp. 85-97.

Zakaria, Fareed (2004), 'Islam, Democracy and Constitutional Liberalism', Political Science Quarterly, 119(1), pp. 1-20.

Youngs, Richard (2004), 'Normative Dynamics and Strategic Interests in the EU's External Identity', Journal of Common Market Studies, 42(2), pp. 415-435. 